\title{
Reproductive consequences of flower damage in two contrasting habitats: The case of Viola portalesia (Violaceae) in Chile
}

\author{
Consecuencias reproductivas del daño floral en dos hábitats contrastantes: el caso de Viola \\ portalesia (Violaceae) en Chile \\ CLAUDIA L. ESPINOZA, MAUREEN MURÚA, RAMIRO O. BUSTAMANTE, VÍCTOR H. MARÍN \\ \& RODRIGO MEDEL* \\ ${ }^{1}$ Departamento de Ciencias Ecológicas, Facultad de Ciencias, Universidad de Chile, Las Palmeras 3425, Casilla 653, Santiago, \\ Chile \\ ${ }^{*}$ Corresponding author: rmedel@gmail.com
}

\begin{abstract}
The indirect impact of flower herbivory on plant reproduction depends on the pollination environment, particularly on the presence or absence of pollinator species with the ability to discriminate damaged from undamaged flowers. The change in pollinator assemblages, due to habitat modification, may modify the impact of flower herbivory on plant reproductive success. In this work, we evaluate the effect of flower herbivory on the seed production of Viola portalesia (Gay) in two contrasting environments, a native and low-disturbed habitat and an extensively transformed habitat characterized by Pinus radiata plantations. Even though the two habitats differed substantially in the composition of pollinator assemblages and visitation rate, the flower damage performed on different petals had no impact on seed production neither within nor between habitats, indicating that change in pollinator assemblages have no indirect reproductive impact via discrimination of damaged flowers. There was a strong habitat effect, however, for seed production, being higher in the pine plantation than in the native habitat. Seed production on a per flower basis increased at a higher rate with the number of flowers in the pine plantation, which suggests a numerical response of pollinators to changes in food availability in this habitat.
\end{abstract}

Key words: flower herbivory, habitat loss, Maulino forest, Pinus radiata, pollination.

\section{RESUMEN}

El impacto indirecto de la herbivoría floral sobre la reproducción de las plantas puede depender del ambiente de polinización, particularmente de la presencia o ausencia de especies de polinizadores con capacidad de discriminar entre las flores dañadas y no dañadas. El cambio en el ensamble de polinizadores, debido a la modificación del hábitat, puede alterar el impacto de la herbivoría floral sobre el éxito reproductivo de las plantas. En este trabajo, se evaluó el efecto de la herbivoría floral sobre la producción de semillas de Viola portalesia (Gay) en dos ambientes contrastantes, un hábitat nativo, con bajos niveles de perturbación y otro hábitat altamente intervenido por plantaciones de Pinus radiata. Aún cuando los dos hábitats difirieron substancialmente en la composición del ensamble de polinizadores y tasas de visitas, el daño floral realizado sobre los diferentes pétalos no tuvo efectos sobre la producción de semillas ni dentro ni entre hábitats, indicando que el cambio en el ensamble de polinizadores no tiene impacto reproductivo a través de la discriminación de flores dañadas. Se observó, sin embargo, un fuerte efecto del hábitat sobre la producción de semillas siendo ésta mayor en la plantación de pino que en el hábitat nativo. La producción de semillas por flor relativa al número de flores aumentó a una mayor tasa en la plantación de pino, lo cual sugiere una respuesta numérica de los polinizadores a cambios en la disponibilidad de alimento en este hábitat.

Palabras clave: bosque Maulino, herbivoría floral, pérdida de hábitat, Pinus radiata, polinización.

\section{INTRODUCTION}

The impact of flower herbivory on plant reproductive success may vary from strong negative effects (Mothershead \& Marquis 2000) to neutral effects (Malo et al. 2001), depending on the pollination environment
(McCall \& Irwin 2006). In general, flower herbivory may have a direct impact on reproductive success by damaging the reproductive structure of flowers and also an indirect effect on reproduction by altering the flower characters involved in pollinator 
attraction (e.g., Herrera et al. 2002, McCall \& Irwin 2006, Pohl et al. 2006). For example, flower herbivory has been shown to influence the quality and quantity of diverse flower traits such as petal size (Mothershead \& Marquis 2000), nectar production (Krupnick \& Weis 1999), flower production (Lohman et al. 1996, McCall \& Irwin 2006) and flowering time (Frazee \& Marquis 1994), all characters that influence pollinator attraction and the quality and quantity of pollination service (Cunningham 1995, Krupnick \& Weis 1999, Mothershead \& Marquis 2000). The most obvious consequence of a reduction or loss of pollination service is the reduction in fruit set and seed set (e.g., Aguilar \& Galetto 2004, Aguilar et al. 2006). Notwithstanding, pollinator species often differ in their ability to distinguish damaged from undamaged flowers (Schaefer et al. 2004), which suggests the final outcome of flower herbivory may be contingent to the composition of the pollinator assemblage (Pohl et al. 2006). One of the most conspicuous effects of habitat loss is the alteration in the composition and abundance of pollinator assemblages, as well as the behavioral change of particular pollinator species (e.g., Didham et al. 1996, Thomas et al. 2001, Goverde et al. 2002). Less obvious are effects on pollination service caused by habitat modification that propagate indirectly to plant reproduction through changes in the response of pollinator assemblages to flower damage. If habitat change modifies the composition and abundance of pollinator assemblages it is likely that the effect of flower damage in reducing pollinator service depends on the presence or absence of particular pollinator species sensitive to habitat alteration. While many studies have examined the effect of habitat change on the composition of pollinator assemblages (e.g., Rathcke and Jules 1993, Murcia 1996, Cunningham 2000, Aizen \& Feinsinger 2004, Murúa et al. 2010), to our knowledge evidence for an indirect role of habitat change on flower herbivory and plant reproductive success is lacking.

The aim of this study is to examine the effect of flower damage on the reproductive success of Viola portalesia in contrasting habitats of the Maulino forest. We will also evaluate the impact of floral damage as a function of flower density, which will provide information on the potential density-dependent effects on plant fitness. More specifically, we will attempt to answer the following questions: 1) Do native and pine plantation habitats differ in the composition of pollinator assemblages? 2) Does flower damage affect seed production in native and pine plantation habitats? 3) To what extent, variation in seed production can be ascribed to changes in the pollination environment between habitats? These questions relate to a more general, 4) Do differences exist in the indirect impact of flower damage on plant reproductive success between the native and modified habitat?

\section{METHODS}

Viola portalesia (Violaceae) is an endemic selfincompatible herb species that distributes along the Costal Range in central Chile. Its flowering season spans from September - November, after which a trivalve fruit is produced. Viola portalesia inhabits indistinctly natural and pine plantation habitats in the Maulino forest, a natural forest that has been extensively subject to human-induced alteration, mainly through deforestation and subsequent replacement of the native forest by plantations of Pinus radiata D. Don (Bustamante et al. 2003). This practice has produced a highly fragmented landscape of native habitat embedded in a matrix of Pinus that leads to an ample variation in the abundance and species richness of diverse functional groups (Grez et al. 2006).

Fieldwork was performed in two contrasting populations of Los Ruiles National Reserve and surrounding areas from October 2007 to January 2008, thereby covering the complete flowering season of $V$. portalesia. The first population was located within the National Reserve ( $\left.35^{\circ} 83^{\prime} \mathrm{S} ; 72^{\circ} 50^{\prime} \mathrm{W}\right)$. The most representative species at the Reserve are Nothofagus alessandri, Nothofagus glauca, Ugni molinae, Oxalis articulata, Teline monspessulana, and Viola portalesia. The second population was embedded in a matrix of Pinus radiata located $3.6 \mathrm{~km}$ from the first population (35 ${ }^{\circ} 85^{\prime}$ S; $\left.72^{\circ} 46^{\prime} \mathrm{W}\right)$. The Pinus plantation was 20 year old, and had an understory with a low herb and shrub species richness that included Azara integrifolia, Lithraea caustica, Ugni molinae and Viola portalesia as the most representative species.

We performed experimental damage on 63 plants in the National Reserve and 59 plants in the Pinus plantation. Only plants with at least four flower buds were chosen. As pollinators may respond to the flower number in the neighborhood of the focal plant of $V$. portalesia, we recorded the number of flowers in a circular area $2 \mathrm{~m}$ diameter around the focal plant. The number of flowers per patch ranged between 1-110 in the native forest and 1-115 flowers in the pine plantation habitat. We allocated 1-day flowers to one of four treatments per plant: 1) removal of the landing petal, 2) removal of the lower petals, 3) removal of the upper petals, and 4) control flower without damage (Fig. 1). The total area of the petals removed was kept as constant as possible in all treatments. In addition to experimental treatments, we estimated the frequency of natural flower herbivory by recording the number of flowers damaged 

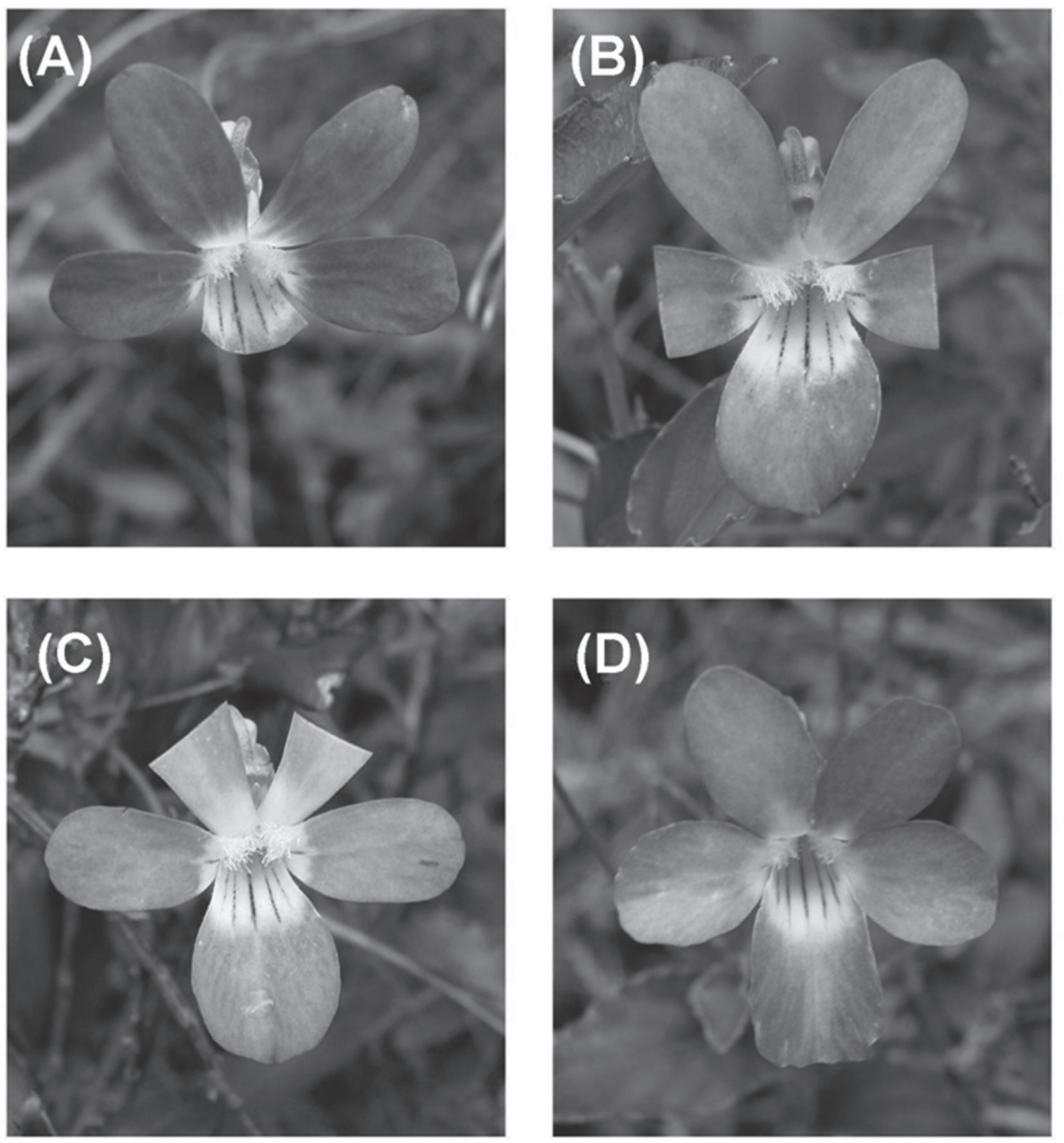

Fig. 1: Description of treatments applied to petals of Viola portalesia. A) Removal of the landing petal (T1), B) removal of the lateral petals (T2), C) removal of the upper petals (T3), D) control without petal removal (T4).

Descripción de los tratamientos aplicados a los pétalos de Viola portalesia. A) Remoción del pétalo de aterrizaje (T1), B) remoción de los pétalos laterales (T2), C) remoción de los pétalos superiores (T3), D) control sin remoción de pétalos (T4).

in 50 replicated plants per habitat, one randomly chosen flower per plant.

To ensure that potential response of pollinators is due to damage and not to a loss of symmetry, the removal of petals was performed on the left and right petals both in the lower and upper petal removal treatment, keeping constant the original symmetry of the flower. We checked for potential withering or additional damage of flowers on a daily basis. Flowers with natural damage were not considered in subsequent analyses. After four weeks of the experimental damage we collected the capsules of 56 and 54 plants in the Reserve and Pinus plantation, respectively. All capsules were analyzed for seed counting in the laboratory. To test the importance of treatment and population on the seed production per flower, we performed one-way analysis of covariance using the number of flowers in the neighborhood as covariate. All data were logtransfomed to fulfill the assumptions of normality and homoscedasticity. Because all the four treatments were performed within replicated plants, data were also analyzed in the context of mixed models to remove the within-plant variance component.
The pollinator assemblage was recorded at each population by quantifying the pollinator species richness and visitation rate, measured as the number of visits per flower per hour using the plant focal method (Dafni et al. 2005). Visitation rate was estimated by recording the number of pollinator visits to all flowers within patches during 15 minutes focal censuses (see also Murúa et al. 2010, Rivera-Hutinel et al 2012). We performed a total of 190 censuses ( $47.5 \mathrm{~h}$ of observation) in the native habitat and 108 censuses ( $27 \mathrm{~h}$ of observation) in the Pinus plantation All samplings were performed between 0900 and 1700 hours, always in sunny days. Only insects that contacted the reproductive structures of flowers were considered as legitimate visitors. Visitation rate to $V$. portalesia was compared between populations by using a generalized linear model with Poisson distribution. All statistical analyses were performed in R package (2007).

\section{RESULTS}

The composition and species richness of pollinator assemblages differed between 
TABLE 1

List of species involved in the pollination process of Viola portalesia in native and pine plantation habitats. Mean visitation rate and standard error on a per species basis are depicted. $\dagger$ NF: not found in the habitat.

Lista de especies involucradas en el proceso de polinización de Viola portalesia en los hábitats nativo y plantación de pino. La tasa de visita promedio $( \pm \mathrm{SE})$ de cada ensamble de polinizadores es presentada. $\dagger \mathrm{NF}$ : no encontrado en el hábitat.

\begin{tabular}{|c|c|c|c|}
\hline \multirow[b]{2}{*}{ Order } & \multirow[b]{2}{*}{ Species } & \multicolumn{2}{|c|}{$\begin{array}{c}\text { Visitation rate } \\
\text { (Visits flower-1 hour-1) }\end{array}$} \\
\hline & & Native & Pine plantation \\
\hline \multirow[t]{12}{*}{ Hymenoptera } & Bombus dahlbomii & $0.008 \pm 0.002$ & $0.002 \pm 0.002$ \\
\hline & Bombus terrestris & NF & $0.034 \pm 0.034$ \\
\hline & Centris cineraria & NF & $0.002 \pm 0.002$ \\
\hline & Chilicola chalcidiformis & NF & $0.136 \pm 0.062$ \\
\hline & Corynura chloris & $0.002 \pm 0.001$ & $\mathrm{NF}$ \\
\hline & Diphaglosa gayi & $0.001 \pm 0.000$ & $\mathrm{NF}$ \\
\hline & Iridomyrmex oblonga & $0.012 \pm 0.003$ & $\mathrm{NF}$ \\
\hline & Lasioglossum spinolae & NF & $0.003 \pm 0.003$ \\
\hline & Manuelia gayi & $0.003 \pm 0.001$ & $\mathrm{NF}$ \\
\hline & Manuelia gayatina & $0.107 \pm 0.027$ & $0.087 \pm 0.052$ \\
\hline & Manuelia postica & $0.057 \pm 0.014$ & $\mathrm{NF}$ \\
\hline & Solenopsis gayi & NF & $0.048 \pm 0.036$ \\
\hline \multirow[t]{8}{*}{ Diptera } & Acrophthalmyda paulseni & $\mathrm{NF}$ & $0.076 \pm 0.069$ \\
\hline & Caenopangonia brevirostris & $0.002 \pm 0.001$ & NF \\
\hline & Lasia corvine & $0.002 \pm 0.0001$ & $\mathrm{NF}$ \\
\hline & Megalybus crassus & $0.026 \pm 0.006$ & $\mathrm{NF}$ \\
\hline & Platycheirus punctulata & $0.012 \pm 0.003$ & NF \\
\hline & Sirphid unidentified & $0.041 \pm 0.010$ & $\mathrm{NF}$ \\
\hline & Trichophthalma landbecki & NF & $0.015 \pm 0.009$ \\
\hline & Triploechus heteroneurus & $0.002(0.000)$ & $0.006 \pm 0.006$ \\
\hline \multirow[t]{6}{*}{ Coleoptera } & Amecocerus aluthaceithorax & NF & $0.048 \pm 0.036$ \\
\hline & Amecocerus elguetai & NF & $0.006 \pm 0.006$ \\
\hline & Arthrobrachus nigromaculatus & NF & $0.692 \pm 0.138$ \\
\hline & Colastus sp. & $\mathrm{NF}$ & $0.034 \pm 0.034$ \\
\hline & Eucalus tessellatus & $0.007 \pm 0.002$ & $\mathrm{NF}$ \\
\hline & Hylodanacea ruficollis & $\mathrm{NF}$ & $0.006 \pm 0.006$ \\
\hline \multirow[t]{5}{*}{ Lepidoptera } & Homeonympha humilis & $0.006 \pm 0.001$ & $\mathrm{NF}$ \\
\hline & Hylephila venusta & $\mathrm{NF}$ & $0.009 \pm 0.009$ \\
\hline & Vannesa terpsichore & $0.001 \pm 0.003$ & $0.034 \pm 0.034$ \\
\hline & Yramea cytheris & $\mathrm{NF}$ & $0.121 \pm 0.061$ \\
\hline & Mean visitation rate $\pm \mathrm{SE}$ & $0.018 \pm 0.007$ & $0.076 \pm 0.04$ \\
\hline
\end{tabular}


habitats. While flowers in the native habitat received 16 pollinator species, the population of $V$. portalesia in the pine plantation habitat was visited by 18 species. Only four pollinator species were shared between populations. The pollinator taxa most represented in the National Reserve were hymenoptera (44\%) and diptera (38\%). In the Pinus plantation, hymenoptera (39\%) and coleoptera (28\%) were the most represented pollinator taxa. These results suggest that habitat differences are sufficiently strong to determine a different pollinator fauna associated to the two nearby populations of $V$. portalesia. The mean visitation rate per pollinator species was higher in the pine plantation than native habitat (Table 1; Student t-test, $\left.\mathrm{t}_{1,28}=2.75 ; \mathrm{P}=0.004\right)$, which probably results from the presence and high visitation rate shown by Arthrobrachus nigromaculatus in the Pinus habitat (Table 1). Finally, the overall visitation rate taking all insects as a whole, regardless of its species identity, was also higher in the pine plantation than in the native habitat (mean $\pm \mathrm{SE}$, native $=0.27 \pm 0.06$; Pinus plantation $=0.44 \pm 0.13$; Generalized Linear Model, $\chi^{2}{ }_{1}=4.27 ; \mathrm{P}<0.038$ ), confirming that flowers of $V$. portalesia receive a higher visitation rate at the Pinus plantation than at the National Reserve.

Regarding flower herbivory, the frequency of natural floral damage was similar between populations. Eleven out of fifty flowers from different plants $(22 \%)$ presented flower herbivory in the Reserve and fourteen out of fifty flowers (28\%) were herbivorized in the Pinus habitat (Chi-square test, $\chi^{2}{ }_{1}=$ $0.48 ; \mathrm{P}=0.488$ ). It is likely that similarity in natural florivory levels between habitats does not convey differences in seed production as suggested by experimental results. For instance, artificial damage treatments revealed that while habitat and number of flowers per patch had an important effect on seed production, the experimental flower damage imposed on corollas had no significant effect (Table 2, Fig. 2). Flowers of $V$. portalesia inhabiting the native forest produced $40 \%$ less seeds than flowers in the Pinus plantation (mean $\pm \mathrm{SE} ; 15.8 \pm 0.24, \mathrm{n}=224$ versus 22.1 $\pm 0.37, \mathrm{n}=216$, respectively; $\mathrm{P}<0.0001)$. The statistical interaction between habitat-type and flower number per patch was also significant $(\mathrm{P}=0.0006)$, indicating that habitats differed in seed production after keeping constant the number of flowers per patch (Table 2, Fig. 3). Seed production increased at a higher rate in the pine plantation than in the native habitat (Fig. 3). The interaction term including habitat $\mathrm{x}$ treatment, and treatment $\mathrm{x}$ flower number was unimportant in accounting for variation in seed production (Table 2). This result did not change substantially after removal of withinplant variation in Mixed Linear Models $\left(\mathrm{F}_{3,318}=\right.$ $1.50 ; \mathrm{P}=0.214$ ).

TABLE 2

Summary of effects of ANCOVA of habitat $(\mathrm{H})$ and flower treatment $(\mathrm{T})$ impact on seed production in Viola portalesia using flower number per patch (F) as covariate. Degrees of freedom (df), mean squares (MS), F-values, and P-level are listed.

Resumen de los efectos de ANCOVA para impacto del hábitat $(\mathrm{H})$ y tratamiento floral $(\mathrm{T})$ sobre la producción de semillas en Viola portalesia usando el número de flores por parche (F) como covariable. Grados de libertad (df), cuadrados medios (MS), valores de F, y nivel de P son indicados.

\begin{tabular}{lcccc}
\hline Source of variation & df & MS & F & P \\
\hline Habitat $(\mathrm{H})$ & 1 & 4505.9 & 220.30 & $<0.001$ \\
Treatment (T) & 3 & 11.3 & 0.55 & 0.647 \\
Flowers per patch (F) & 1 & 124.0 & 6.06 & 0.014 \\
H x T & 3 & 5.0 & 0.24 & 0.866 \\
Tx F & 3 & 7.3 & 0.36 & 0.785 \\
Hx F & 1 & 243.3 & 11.90 & $<0.001$ \\
Hx Tx F & 3 & 9.6 & 0.47 & 0.702 \\
\hline
\end{tabular}




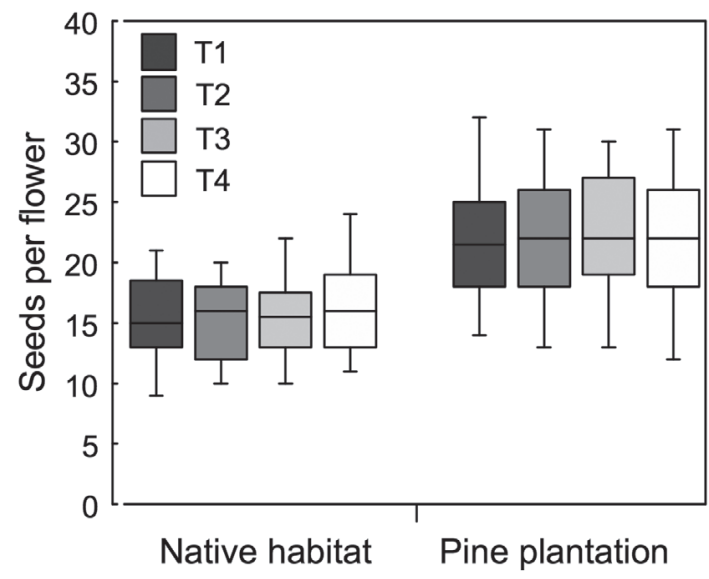

Fig. 2: Box and whisker plot for seed production in each of the four petal removal treatments applied to Viola portalesia in native and pine plantation habitats. Treatments as in Figure 1. Boxes represent the two quartiles around the median of data. Horizontal line within boxes indicates the median of seed production. Whiskers represent the $5^{\text {th }}$ and $95^{\text {th }}$ percentile of data distribution. Outliers are no depicted for clarity purposes.

Producción de semillas en cada uno de los cuatro tratamientos de remoción de pétalos aplicados a Viola portalesia en los hábitats nativo y plantación de pino. Las cajas representan los dos quartiles alrededor de la mediana de los datos. La línea horizontal dentro de las cajas indica la mediana de la producción de semillas. Las barras representan los percentiles 5 y 95 de la distribución de los datos. Valores atípicos no son ilustrados para mayor claridad.

\section{DISCUSSION}

We did not find significant effects of flower damage on seed production among treatments within habitats, indicating that pollinators were largely insensitive to the location of flower damage. Three lines of reasoning may help to understand these results. One possibility is that the quality and quantity of damage that we applied to petals did not emulate natural herbivory. Several studies have reported that insects often use flower symmetry and spatial pattern to guide their foraging activities and flower preferences (Bell 1985, Johnson et al. 1995, Moller \& Eriksson 1995, Giurfa \& Lehrer 2001). The location of damage may influence the impact of flower herbivory on reproductive success. For example, Pohl et al. (2006) reported that flowers damaged on the landing petal in Mimulus luteus produced fewer seeds than flowers damaged in other petals. Likewise,
Sánchez-Lafuente (2007) reported that removal of lower petals alone or in combination with the removal of upper petals had a strong negative impact on pollinator visitation and seed production in Linaria lilacina. Because our treatments consisted on damage on all petals (landing petal, lower petals, and upper petals), keeping as constant as possible the flower symmetry (Fig. 1), it is unlikely this factor accounts for the absence of effect of flower herbivory on seed production within habitats. Regardless of location, however, it is likely that the amount of damage imposed to flowers, that is, the area removed with respect to the total corolla area, was not sufficient for pollinators to reject damaged flowers. Even though we removed about $50 \%$ of the petal area at each treatment ( $25 \%$ of each lower and upper petals), we can not assure this amount is sufficient to elicit rejection of damaged flowers by insect pollinators.

Second, in addition to the potential limitation of the experimental procedure, factors unrelated to flower herbivory may be important for flower discrimination by pollinators. For example, regardless of changes in flower morphology, pollinators may discriminate flowers on the base of additional clues such as the level of floral reward (Krupnick et al. 1999), the presence of chemical signals (Galen et al. 1987, Ashman et al. 2005), and the presence of damaged flowers in the neighborhood of focal plants (Krupnick et al. 1999).

Third, we measured the reproductive impact of flower damage on seed production only, assuming that female and male reproductive success are correlated variables. However, it is known that herbivory may not only influence the female but also the male fitness component (e.g., Mutikainen \& Delph 1996, Krupnick \& Weis 1999, Lehtila \& Strauss 1999). Because we did not measure pollen export, pollen tube growth rates, or siring success, we cannot rule out that flower herbivores reduced male rather than female fitness in this species. The absence of effect of a modified corolla on seed production suggests that pollinators have a low impact as agents of natural selection in these species. For instance, complementary information has revealed weak pollinator-mediated selection coefficients on the flower phenotype of $V$. portalesia in the two populations (Murúa et 
al. 2010). These results together indicate that no clear function related with the pollination process can be ascribed to petals in this species. Similar results have been previously reported in other studies. For example, Herrera (1993) rejected the hypothesis of adaptation of corolla spur to hawk moth pollination in Viola cazorlensis (Violaceae). Similarly, Malo et al. (2001) observed that experimental corolla modification had no effect on pollination and reproductive success in Myrmecophila tibicinis (Orchidaceae). Future studies need to explicitly address the ecological conditions under which floral damage is expected to have a negative impact on plant reproductive success.

Even though herbivory treatments were largely irrelevant in accounting for variation in seed production, there was a strong habitat effect (Table 2). Seed production was lower in the native habitat than in the Pinus plantation, which raises the question on the factors that

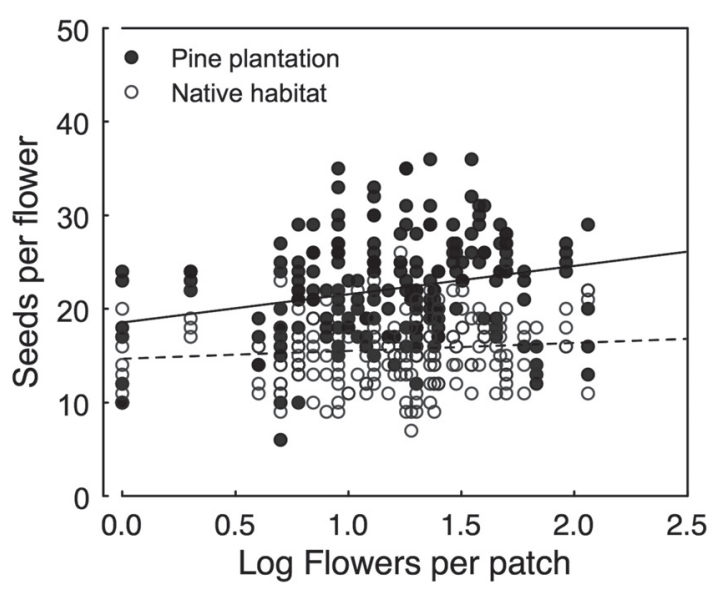

Fig. 3: Results of ANCOVA of flower number per patch on seed production per flower by habitat type. Filled dots are flowers of $V$. portalesia in the pine plantation and open dots are flowers in the native habitat. Continuous and dashed lines represent the best linear fit in the pine plantation (slope \pm SE: 3.01 $\left.\pm 0.84, \mathrm{r}^{2}=0.06, \mathrm{n}=2, \mathrm{P}<0.001\right)$ and native habitat $\left(0.41 \pm 0.54, \mathrm{r}^{2}=0.01, \mathrm{n}=224, \mathrm{P}=0.448\right)$, respectively.

Resultados de ANCOVA del número de flores por parche sobre la producción de semillas por flor por tipo de hábitat. Círculos llenos representan flores de $V$. portalesia en la plantación de pino y círculos abiertos representan flores en el hábitat nativo. Las líneas continuas y segmentadas representan el mejor ajuste lineal en los hábitats de Pinus radiata (pendiente \pm EE: $\left.3.01 \pm 0.84, \mathrm{r}^{2}=0.06, \mathrm{n}=214, \mathrm{P}<0.001\right)$ y nativo $(0.41 \pm$ $\left.0.54, \mathrm{r}^{2}=0.01, \mathrm{n}=224, \mathrm{P}=0.448\right)$, respectivamente. contribute to variation in seed production between habitats. There are several factors potentially relevant to explain this pattern. In principle, the higher visitation rate detected in the pine plantation might be sufficient to account for the higher seed production in this habitat. However, only $13.3 \%$ of pollinator species were shared between habitats, which suggests that visitation rate may not be necessarily comparable between native and pine habitats. Variation in the efficiency of pollinators between habitats has been suggested as an important factor to explain variation in seed production among populations (e.g., Prada et al. 1998, Sanchez-Lafuente et al. 1999). In our study, the pollinator species with the highest visitation rate differed between habitats (the bee Manuelia gayatina in the native habitat and the beetle Arthrobrachus nigromaculatus in the pine plantation, see Table 1). Even though the efficiency of such species is unknown at present, it is likely that differences in the composition of pollinator assemblages imply a completely different spectrum of species with varying efficiency at pollen deposition. A second, non-mutually exclusive explanation bases on plant species richness and pollen interference. It is known that interference associated to increased foreign pollen deposition in rich-species plant communities may reduce successful fertilization in comparison to poor-species plant communities (Waser \& Fugate 1986, Murphy \& Aarsen 1995, Totland 2001, Hegland $\&$ Totland 2008). The two habitats compared in this study differed substantially in plant species richness. While 63 flowering species occurred in the natural Reserve, only 17 flowering species accompanied $V$. portalesia in the pine plantation. This notorious asymmetry suggests that seed production is more likely to be pollinator-limited in the native habitat. In this way, the reduction in flowering plant diversity observed in the Pinus plantation may lead to a lower foreign pollen deposition in stigmas of $V$. portalesia. Third, the high metabolic rates of flying insects create a high demand for food, and the patterns of occurrence of pollinators tend to track the spatial and temporal patterns of food availability (Bronstein 1995). In doing so, numerical responses of pollinator species to flower number might be more prevalent in habitats with low food availability, that is, 
in poor habitats where any increase in flower number should result in a higher visitation rate and seed production per flower. Indirect evidence for this hypothesis comes from the observation that seed production increased at a higher rate with flower number at the Pinus plantation than native habitat (Fig. 3). The extent to which the higher seed production observed in the pine plantation results as a consequence of a change in pollinator assemblages and species efficiency, pollen interference at stigmas, or from a numerical response of pollinator species in poor habitats needs to be assessed in future studies.

In conclusion, our results indicate that the strong differences in the composition of pollinator assemblages and visitation rate between habitats do not translate into important reproductive effects through flower herbivory. As pollinators do not discriminate against damaged flowers, they were largely inconsequential for indirect effects of flower herbivory on plant reproduction. The higher seed production of $V$. portalesia observed in the transformed habitat cannot be ascribed to variation in flower herbivory. Rather, factors unrelated to flower herbivory, such as variation in the composition and efficiency of the pollination assemblage, variation in the accompanying flora, and numerical responses of pollinators to changes in food availability seem to be important to understand the higher seed production observed in the $P$. radiata plantation as compared to the native habitat.

ACKNOWLEDGEMENTS: This research was funded by grants ACT 34/2006 and FONDECYT 1120155. We thank Antonio Rivera, Gioconda López and Marcela Torres for their invaluable collaboration in different steps of this study.

\section{LITERATURE CITED}

AGUILAR R \& L GALETTO (2004) Effects of forest fragmentation on male and female reproductive success in Centrum parqui. Oecologia 138: 513520.

AGUILAR R, L ASHWORTH, L GALETTO \& MA AIZEN (2006) Plant reproductive susceptibility to habitat fragmentation: Review and synthesis through a meta-analysis. Ecology Letters 9: 968-980.

AIZEN MA \& P FEINSINGER (1994) Habitat fragmentation, pollination, and plant reproduction in a chaco dry forest, Argentina. Ecology 75: 330351.

ASHMAN TL, M BRADBURN, DH COLE, BH BLANEY \& RA RAGUSO (2005) The scent of a male: The role of floral volatiles in pollination of a gender dimorphic plant. Ecology 86: 2099-2105.

BELL G (1985) On the function of flowers. Proceedings of the Royal Society of London B 224: 223-265.

BRONSTEIN JL (1995) The plant-pollinator landscape. In: Hansson L, L Fahrig \& G Merriam (eds) Mosaic landscapes and ecological processes: 256288. Chapman and Hall, London.

BUSTAMANTE RO, IA SEREY \& ST PICKET (2003) Forest fragmentation, plant regeneration and invasion processes across edges in central Chile. In: Bradshaw GA \& PA Marquet (eds) How landscapes change: Human disturbance and ecosystem fragmentation in the Americas: 145160. Springer-Verlag, Berlin.

CUNNINGHAM SA (1995) Ecological constraints on fruit initiation by Calyptrogyne ghiesbreghtiana (Arecaceae): Floral herbivory, pollen availability and visitation by pollinating bats. American Journal of Botany 82: 1527-1536.

CUNNINGHAM SA (2000) Depressed pollination in habitat fragments causes low fruit set. Proceedings of the Royal Society of London B 267: 1149-1152.

DAFNI A, PG KEVAN \& BC HUSBAND (eds) (2005) Practical pollination biology. Enviroquest Ltd. Cambridge, Ontario.

DIDHAM R, J GHAZOUL, N STORK \& AJ DAVIS (1996) Insects in fragmented forests: A functional approach. Trends in Ecology and Evolution 11: 255-260.

FRAZEE J \& R MARQUIS (1994) Environmental contribution to floral trait variation in Chamaecrista fasciculata. American Journal of Botany 81: 206-215.

GALEN C, KA ZIMMER \& ME NEWPORT (1987) Pollination in floral scent morphs of Polemonium viscosum: A mechanism for disruptive selection on the flowers size. Evolution 41: 599-606.

GOVERDE M, K SCHWEIZER, B BAUR \& A ERHARDT (2002) Small-scale habitat fragmentation effects on pollinator behavior: Experimental evidence from the bumblebee Bombus veteranus on calcareous grasslands. Biological Conservation 104: 293-299.

GIURFA M \& M LEHRER (2001) Honeybee vision and floral displays: From detection to close-up recognition. In: Chittka L \& JD Thomson (eds) Cognitive ecology of pollination: Animal behavior and floral evolution: 61-82. Cambridge University Press, Cambridge.

GREZ AA, JA SIMONETTI \& RO BUSTAMANTE (eds) (2006) Biodiversidad en ambientes fragmentados de Chile: Patrones y procesos a diferentes escalas. Editorial Universitaria, Santiago, Chile.

HEGLAND SJ \& O TOTLAND (2008) Is the magnitude of pollen limitation in a plant community affected by pollinator visitation and plant species specialisation levels? Oikos 117: 883-891.

HERRERA CM (1993) Selection on floral morphology and environmental determinants of fecundity in a hawk moth-pollinated violet. Ecological Monographs 63: 251-275.

HERRERA CM, M MEDRANO, P REY, AM SÁNCHEZLAFUENTE, MB GARCÍA ET AL. (2002) Interaction of pollinators and herbivores on plant fitness suggests a pathway for correlated evolution of mutualism and antagonism related traits. Proceedings of the National Academy of Sciences USA 99: 16823-16828. 
JOHNSON SG, LF DELPH \& CL ELDERKIN (1995) The effect of petal-size manipulation on pollen removal, seed set, and insect-visitor behavior in Campanula americana. Oecologia 102: 174-179.

KRUPNICK GA, AE WEIS \& DR CAMPBELL (1999) The consequences of floral herbivory for pollinator service to Isomeris arborea. Ecology 80: 125-134.

KRUPNICK GA \& AE WEIS (1999) The effect of floral herbivory on male and female reproductive success in Isomeris arborea. Ecology 80: 135-149.

LEHTILA K \& SY STRAUSS (1999) Effects of foliar herbivory on male and female reproductive traits of wild radish, Raphanus raphanistrum. Ecology 80: $116-124$.

LOHMAN DJ, AR ZANGERL \& MR BERENBAUM (1996) Impact of floral herbivory by parsnip webworm (Oecophoridae: Depressaria pastinacella Duponchel) on pollination and fitness of wild parsnip (Apiaceae: Pastinaca sativa). American Midland Naturalist 136: 407-412.

MALO JE, J LEIRANA-ALCOCER \& V PARRA-TABLA (2001) Population fragmentation, florivory, and the effects of flower morphology alterations on the pollination success of Myrmecophila tibicinis (Orchidaceae). Biotropica 33: 529-534.

MCCALL AC \& RE IRWIN (2006) Florivory: The intersection of pollination and herbivory. Ecology Letters 9: 1351-1365.

MOLLER AP \& M ERIKSSON (1995) Pollinator preference for symmetrical flowers and sexual selection in plants. Oikos 73: 15-22.

MOTHERSHEAD K \& RJ MARQUIS (2000) Fitness impacts of herbivory through indirect effects on plant-pollinator interactions in Oenothera macrocarpa. Ecology 81: 30-40.

MURCIA C (1996) Forest fragmentation and the pollination of Neotropical plants. In: Schelhas J \& R Greenberg (eds) Forest patches in tropical landscapes: 19-36. Island Press, Covelo, California.

MURPHY SD \& LW AARSEN (1995) Reduced seed set in Elytrigia repens caused by allelopathic pollen from Phleum pratense. Canadian Journal of Botany 73: 1417-1422.

MURÚA M, C ESPINOZA, RO BUSTAMANTE, V MARÍN \& R MEDEL (2010) Does human-induced habitat transformation modify pollinator-mediated selection?. Oecologia 163: 153-162.
MUTIKAINEN P \& L DELPH (1996) Effects of herbivory on male reproductive success in plants. Oikos 75: 353-358.

POHL N, G CARVALLO, C BOTTO-MAHAN \& R MEDEL (2006) Nonadditive effects of flower damage and hummingbird pollination on the fecundity of Mimulus luteus. Oecologia 149: 648655.PRADA M, D MOLINA, D VILLARROEL, R BARRIOS \& A DÍAZ (1998) Efectividad de dos especies del género Elaeidobius (Coleoptera: Curculionidae) como polinizadores en palma aceitera. Bioagro 10: 3-10.

R DEVELOPMENT CORE TEAM (2007) R: A language and environment for statistical computing. $\mathrm{R}$ foundation for Statistical Computing, Vienna, Austria. URL: http://www.R-proyect.org/.

RATHCKE BJ \& ES Jules (1993) Habitat fragmentation and plant-pollinator interactions. Current Science 65: 273-277.

RIVERA-HUTINEL A, RO BUSTAMANTE, VH MARÍN \& R MEDEL (2012) Effects of sampling completeness on the structure of plant-pollinator networks. Ecology 93: 1593-1603.

SÁNCHEZ-LAFUENTE AM (2007) Corolla herbivory, pollination success and fruit predation in complex flowers: An experimental study with Linaria lilacina (Scrophulariaceae). Annals of Botany 99: 355-364.

SÁNCHEZ-LAFUENTE AM, P REY \& J ALCANTARA (1999) Breeding system and the role of floral visitors in seed production of a 'few-flowered' perennial herb, Paeonia broteroi Boiss. \& Reut. (Paeoniaceae). Ecoscience 6: 163-172.

SCHAEFER HM, V SCHAEFER \& DJ LEVEY (2004) How plant-animal interactions signal new insights in communication. Trends in Ecology and Evolution 19: 577-584.

THOMAS CD, EJ BODSWORTH, RJ WILSON, AD SIMMONS, ZG DAVIES ET AL. (2001) Ecological and evolutionary processes at expanding range margins. Nature 411: 577-581.

TOTLAND O (2001) Environment-dependent pollen limitation and selection on floral traits in an alpine species. Ecology 82: 2233-2244.

WASER NM \& ML FUGATE (1986) Pollen precedence and stigma closure: A mechanism of

competition for pollination between Delphinium nelsonii and Ipomopsis aggregata. Oecologia 70: 573-577. 
